\title{
Catalytic deoxygenation of model compounds from flash pyrolysis of lignocellulosic biomass over activated charcoal-based catalysts
}

\author{
Simon Eibner ${ }^{\mathrm{a}, \mathrm{b}}$, Alexandre Margeriat ${ }^{\mathrm{c}}$, François Broust ${ }^{\mathrm{a}}$, Dorothée Laurenti ${ }^{\mathrm{c}}$, \\ Christophe Geantet ${ }^{\mathrm{c}}$, Anne Julbe ${ }^{\mathrm{d}}$, Joël Blin ${ }^{\mathrm{a}, \mathrm{b}, *}$ \\ a CIRAD, UPR BioWooEB, F-34398 Montpellier, France. BioWooEB, Univ Montpellier, CIRAD, Montpellier, France \\ ${ }^{\mathrm{b}}$ Institut International d'Ingénierie de l'Eau et de l'Environnement (2iE), Laboratoire Biomasse Energie et Biocarburants, Rue de la Science 01 BP 594 , \\ Ouagadougou 01, Burkina Faso \\ ${ }^{\mathrm{c}}$ Institut de recherches sur la catalyse et l'environnement de Lyon (IRCELYON), UMR5256 CNRS Université de Lyon, 2 avenue Albert Einstein, 69626 \\ Villeurbanne Cedex, France \\ d Institut Européen des Membranes (IEM), UMR 5635 CNRS-ENSCM-UM, Université de Montpellier (CC 47), Place Eugène Bataillon, 34095 Montpellier \\ Cedex 5, France
}

\section{A B S T R A C T}

Catalytic deoxygenation of pyrolytic vapors represents a great challenge to produce biofuels by flash pyrolysis of lignocellulosic biomass. A wide variety of catalysts, particularly zeolites, have been investigated for this purpose, however, quick deactivation was often reported. Although they are cheap and can have a hierarchical pore structure, activated charcoal-based catalysts have received only little attention. This paper presents an innovative method to synthesize activated charcoal based catalysts doped with $\mathrm{CeO}_{2}, \mathrm{Fe}_{2} \mathrm{O}_{3}$ or $\mathrm{Mn}_{3} \mathrm{O}_{4}$ nanoparticles. We investigated the performances of those catalysts to deoxygenate two biomass pyrolytic model compounds - acetic acid and guaiacol - on a fixed-bed reactor between $350^{\circ} \mathrm{C}$ and $450^{\circ} \mathrm{C}$. Ceria-based catalyst was highly active and remarkably stable to enhance ketonic decarboxylation of acetic acid, leading to the formation of acetone. Huge amounts of produced phenol attest for the partial deoxygenation of guaiacol, particularly when using iron-based catalyst. This study demonstrates the potential of activated charcoal-based catalysts to produce weak-acidic and partially deoxygenated bio-oils.

Keywords:

Activated charcoal

Heterogeneous catalysis

Acetic acid

Guaiacol

Ketonic decarboxylation

\section{Nomenclature}

$X_{R}(t) \quad$ Reaction rate of reactant $\mathrm{r}$ at $\mathrm{t}$

$A_{R}(t)$ and $A_{P}(t)$ GC peak area of reactant $\mathrm{r}$ or product $\mathrm{P}$ at $\mathrm{t}$

$A_{R, 0} \quad$ Initial GC peak area of reactant $\mathrm{r}$

$S_{P, R}(t) \quad$ Selectivity of product $\mathrm{P}$ from conversion of reactant $\mathrm{r}$ at $\mathrm{t}$

$v_{R}$ and $v_{P}$ Stoichiometric numbers relative to reactant $\mathrm{r}$ or product $P$

$k_{P}$ and $k_{R}$ GC response factors relative to reactant $r$ or product $\mathrm{P}$

\footnotetext{
* Corresponding author at: CIRAD, UPR BioWooEB, F-34398 Montpellier, France. BioWooEB, Univ Montpellier, CIRAD, Montpellier, France.

E-mail address: joel.blin@cirad.fr (J. Blin).
}

\section{Introduction}

Flash pyrolysis is undergoing an increasing gain of interest since it represents an attractive way to produce both biofuels and biobased chemicals from abundant lignocellulosic resources. Pyrolytic bio-oils are complex mixtures of organic molecules such as aldehydes, ketones, carboxylic acids, phenolics and sugars [1,2]. The presence of those oxygenated molecules is responsible for both the low energy density of bio-oils - which is roughly divided by a factor two compared to crude oil - and ageing mechanisms [3]. Biooil upgrading techniques have been widely reviewed by Bridgwater et al. [4]. Among them, catalytic upgrading of pyrolysis vapors is a promising way to partially deoxygenate bio-oils and consequently reduce the acidity of bio-oil.

To reach this goal, lot of studies were dedicated to the use of zeolite catalysts, such as ZSM-5 (MFI) [5-18], mordenite $[6,17,19]$, faujasite $[6,9,17,20,21]$, ferrierite $[17,19,22]$, or beta zeolite $[6,17,19,22]$. Other catalytic supports such as MCM-41 [5,23-25], titanium dioxide [26-28], zirconia [26,28], ceria [26], 
Table 1

Experimental conditions for catalytic tests with acetic acid and guaiacol.

\begin{tabular}{lll}
\hline & Acetic acid & Guaiacol \\
\hline Saturation chamber temperature $\left({ }^{\circ} \mathrm{C}\right)$ & 40 & 60 \\
Inert gas & $\mathrm{Ar}$ & $\mathrm{N}_{2}$ \\
Molar flow rate of reactant $(\mu \mathrm{mol} / \mathrm{min})$ & 114 & 7 \\
Catalyst mass $(\mathrm{mg})$ & 50 & 150 \\
WHSV $\left(\mathrm{h}^{-1}\right)$ & 8.1 & 0.3 \\
Catalytic conversion temperature $\left({ }^{\circ} \mathrm{C}\right)$ & {$[350-450]$} & 400 \\
\hline
\end{tabular}

silica $[18,28]$ and alumina $[9,25,29,30]$ were also reported in the literature. Catalyst can be put directly inside the pyrolysis reactor as a bed material [6] or be placed in a fixed bed reactor prior to condensation stage [5]. The use of zeolites is of great interest since they offer both a high surface area and a well-defined pore structure. However, it is largely accepted that zeolites deactivate quite rapidly by coking due to both their surface acidity and pore structure [31]. To overcome this drawback, Neumann et al. investigated the performance of meso-ZSM-5, a catalyst with a hierarchical structure containing both mesopores and micropores [32]. This study clearly demonstrated that mesoporosity reduces coke formation.

To our knowledge, activated charcoal-based catalysts have received little attention to upgrade pyrolysis vapors even if they are cheap, non-acidic - or weakly acidic - and usually combine both mesoporous and microporous networks. It is commonly demonstrated that a very high dispersion of catalytic sites could be obtained over activated charcoals [33,34]. Moreover, carbon support is appropriated to reduce the acidic undesirable side-reactions like demethylation/methylation or cracking [35].

To address bio-oil complexity, the catalyst performance for the conversion of pyrolytic model compounds is generally tested prior to convert biomass pyrolysis vapors. Among the molecules produced during pyrolysis, acetic acid is one of the most oxygenated $(\mathrm{O} / \mathrm{C}=1)$. Furthermore, it accounts for almost $8 \mathrm{wt} . \%$ of bio-oil (on a dry basis) [36] and is largely responsible for bio-oil acidity [37]. Acetic acid can be efficiently converted to acetone by ketonic decarboxylation [38]. This reaction is important since it is a way to both release oxygen by dehydration or by decarboxylation and to provide $C-C$ coupling reactions $[26,39]$. Ketonic decarboxylation reaction kinetics can be enhanced over metal oxide based catalysts such as $\mathrm{CeO}_{2}, \mathrm{Fe}_{2} \mathrm{O}_{3}, \mathrm{MnO}_{2} / \mathrm{Mn}_{3} \mathrm{O}_{4}, \mathrm{TiO}_{2}, \mathrm{ZrO}_{2}$ and $\mathrm{Al}_{2} \mathrm{O}_{3}$ [26,40-47]. The ketonization mechanism involves either a bulk or a surface mechanism, both favored by oxides with low lattice energy or high basicity. This is the case of $\mathrm{CeO}_{2}$ [39] for which it occurs by interaction of two adsorbed molecules on basic sites at the (111) surface [48]. Calaza's paper demonstrated that desorption of acetic acid leads to reduction of $\mathrm{CeO}_{2}$ and that oxygen vacancies formed are strong adsorption sites that trap acetate [48]. Bridge bonded $\mu$ acetate bimolecular coupling reaction forms acetone. $\mathrm{Mn}_{3} \mathrm{O}_{4}$ does not exhibit basic properties but can be reduced easily and form oxygen vacancies which are active for the reaction.

On the other hand, guaiacol is often used as a model compound of lignin monomer derivatives since it is the simplest representative compound which possess phenolic and aromatic bonded methoxy oxygen [49]. Guaiacol derived compounds may account for almost 4 wt.\% of bio-oil (on a dry basis) [36]. During secondary gas phase reactions, guaiacol may decompose to form phenol, catechol and aromatics. Since guaiacol is one of the most refractory compounds to deoxygenation in bio-oil it is of great interest to evaluate its catalytic conversion.

The aim of the present work is to investigate the performances of an activated metal doped charcoal to convert pyrolytic model compounds - acetic acid and guaiacol - into less oxygenated molecules. Activated charcoal-based catalysts are supposed to be less prone to deactivation compared to zeolites since they are non-acidic - or weakly acidic - and partially mesoporous. Catalysts were doped with cerium, manganese and iron oxides which are expected to efficiently favor ketonic decarboxylation reaction. Catalytic performance was determined in a fixed bed catalytic reactor in the temperature range from $350^{\circ} \mathrm{C}$ to $450^{\circ} \mathrm{C}$.

\section{Materials and methods}

\subsection{Catalyst synthesis and characterization}

Biomass-based activated charcoal (Norit RX1.5 EXTRA) was provided by Cabot Corporation. This extruded charcoal $(\varphi=1,5 \mathrm{~mm}$ $\mathrm{L}=5 \mathrm{~mm})$ has a high surface area $\left(\approx 1455 \mathrm{~m}^{2} / \mathrm{g}\right)$ and low ash content ( $<3$ wt.\%). Charcoals were dried overnight at $105^{\circ} \mathrm{C}$ before the impregnation step with nitrate salts.

Nitrate salts - $\mathrm{Ce}\left(\mathrm{NO}_{3}\right)_{3} \cdot 6 \mathrm{H}_{2} \mathrm{O}, \quad \mathrm{Fe}\left(\mathrm{NO}_{3}\right)_{3} \cdot 9 \mathrm{H}_{2} \mathrm{O}$ and $\mathrm{Mn}\left(\mathrm{NO}_{3}\right)_{2} \cdot 4 \mathrm{H}_{2} \mathrm{O}$ - were purchased from Sigma Aldrich (purity $\geq 97 \%$ ). Aqueous solutions of each salt precursor were prepared by dissolving $0.5 \mathrm{~g}$ of nitrate salt in $10 \mathrm{~mL}$ of pure water per gram of charcoal. These solutions, containing the dispersed dried charcoal, were placed in a rotary evaporator at $30 \mathrm{mbar}$ for $15 \mathrm{~min}$ at room temperature. Then, the temperature and pressure were set at $50^{\circ} \mathrm{C}$ and $90 \mathrm{mbar}$, respectively. Pressure was progressively reduced until complete evaporation of water. It has to be noted that the entire nitrate precursor is impregnated inside the pore volume of the charcoal [50]. Impregnated charcoals were then dried overnight at $105^{\circ} \mathrm{C}$ at atmospheric pressure. Thermal degradation of the precursors was then performed in a tubular furnace under $\mathrm{N}_{2}$ flow (for $4 \mathrm{~h}, 5^{\circ} \mathrm{C} / \mathrm{min}$ up to $400^{\circ} \mathrm{C}$, plateau at $400^{\circ} \mathrm{C}$ ). The resulting catalysts were stored in a dry and inert atmosphere. In the following, the Norit activated charcoals will be noted $\mathrm{C}_{\text {norit }}$ and the catalysts doped with cerium, manganese and iron will be noted $\mathrm{CeO}_{\mathrm{x}} / \mathrm{C}_{\text {norit }}, \mathrm{MnO}_{\mathrm{x}} / \mathrm{C}_{\text {norit }}$ and $\mathrm{FeO}_{\mathrm{x}} / \mathrm{C}_{\text {norit }}$. Assuming that the whole nitrate precursor is impregnated in the activated charcoal, theoretical metal amounts are respectively $13.9 \mathrm{wt} \%, 9.9 \% \mathrm{wt} \%$ and $6.5 \mathrm{wt} \%$ for $\mathrm{CeO}_{\mathrm{x}} / \mathrm{C}_{\text {norit }}, \mathrm{MnO}_{\mathrm{x}} / \mathrm{C}_{\text {norit }}$ and $\mathrm{FeO}_{\mathrm{x}} / \mathrm{C}_{\text {norit }}$.

The synthesized catalysts were analyzed by XRD (Bruker D8 Advance A25) and electronic microscopy (HRTEM, JEOL 2010). Mean sizes of crystallites were estimated from the diffraction patterns by using the Scherrer method. Phase composition of the crystallites was determined by comparing the diffraction peaks with reference patterns. Nitrogen adsorption/desorption isotherm of the activated charcoal (previously outgassed at $300^{\circ} \mathrm{C}$ under vacuum for $12 \mathrm{~h}$ ) was plotted for relative pressures ranging from 1 to $5.10^{-6}$ to investigate the porous structure (Micrometrics ASAP 2010). Microporous volumes were determined according to the Dubinin-Radushkevich method which is the more suitable for activated charcoals [51].

\subsection{Catalytic reactor to convert model compounds}

The catalyst performance in acetic acid and guaiacol conversion were carried out in quartz made fixed bed reactor, with a frit bed supporting the catalysts (Fig. 1). Reactants were placed in the saturation chamber maintained at either $40^{\circ} \mathrm{C}$ for acetic acid or $60^{\circ} \mathrm{C}$ for guaiacol to fix appropriate corresponding partial pressure during the test. Vapors were swept by an inert gas, generating flow rates of $114 \mu \mathrm{mol} / \mathrm{min}$ for acetic acid and $7 \mu \mathrm{mol} / \mathrm{min}$ for guaiacol (Table 1).

Catalysts were previously ground and sieved at $100-180 \mu \mathrm{m}$ to reduce pore diffusion limitation. Since guaiacol catalytic conversion under atmospheric pressure was expected to be more difficult than acetic acid conversion, test runs were carried out with $150 \mathrm{mg}$ for guaiacol and $50 \mathrm{mg}$ of catalysts for acetic acid and thus yielding Weight Hourly Space Velocities (WHSV) of $0.3 \mathrm{~h}^{-1}$ and $8.1 \mathrm{~h}^{-1}$, respectively (Table 1 ). 


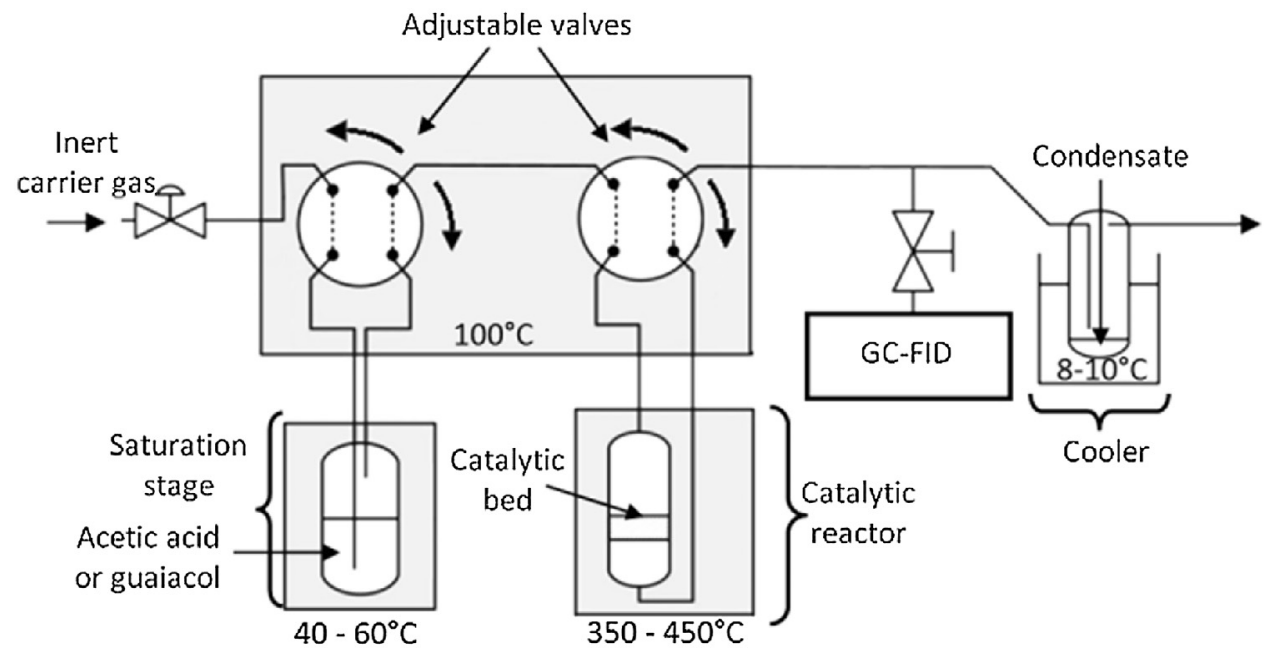

Fig. 1. Schematic representation of the fixed bed catalytic reactor used to convert model compounds. The saturation stage is heated at saturation temperature ( $40{ }^{\circ} \mathrm{C}$ for acetic acid and $60^{\circ} \mathrm{C}$ for guaiacol). Catalytic reactor is heated at reaction temperature (between $350^{\circ} \mathrm{C}$ and $450{ }^{\circ} \mathrm{C}$ ). Valves and connections are heated at $100{ }^{\circ} \mathrm{C}$ to prevent early condensation of the reactant.

Catalytic test runs were performed between $350^{\circ} \mathrm{C}$ and $450^{\circ} \mathrm{C}$. The catalyst bed was heated at the selected reaction temperature, in inert atmosphere for at least $1 \mathrm{~h}$ before starting each experiment. At this stage, the fixed bed reactor was by-passed and reactant (acetic acid or guaiacol) initial concentration was estimated by on-line GCFID. Catalytic tests were started only when the reactant flow rate was constant, referring to the reactant peak area.

\subsection{On-line and off-line gas chromatography analysis}

On-line GC-FID used for acetic acid conversion tests consists on a HP plot Q column $\left(40^{\circ} \mathrm{C}->240^{\circ} \mathrm{C} ; 6^{\circ} \mathrm{C} / \mathrm{min}\right)$ coupled with a FID detector. For guaiacol conversion tests, GC-FID analysis was performed using a CP-Sil $5 \mathrm{CB}$ column $\left(100^{\circ} \mathrm{C}->250^{\circ} \mathrm{C} ; 30^{\circ} \mathrm{C} / \mathrm{min}\right)$. Conversion rates of acetic acid or guaiacol were calculated from reactant peak area (noted $A_{R}$ ) according to Eq. (1).

$X_{R}(t)=1-\frac{A_{R}(t)}{A_{R, 0}}$

Equation 1. Conversion rate of reactant $\mathrm{R}$.

Identification of the reaction products after vapor condensation was performed from previous retention time measurements with expected molecules (acetone, methane, catechol, phenol, o-,p,m-cresol, methanol, benzene, 2-methylphenol, 3-methylphenol, 2,6-dimethyphenol...). For each considered reaction, product selectivities were determined by assuming that response factors $\left(\mathrm{k}_{\mathrm{P}}\right.$ and $\mathrm{k}_{\mathrm{R}}$ ) of the products - phenol, catechol, cresol... for guaiacol conversion; acetone for acetic acid conversion - were equals (Eq. (2)). This assumption is generally accepted when the number of carbon atoms is close [52]. Therefore, selectivity towards product $\mathrm{P}$ (from reactant $\mathrm{R}$ ) is estimated from Eq. (2).

$S_{P, R}(t)=\left|\frac{V_{R}}{V_{P}}\right| \frac{k_{P} A_{P}(t)}{k_{R} A_{R, 0} X_{R}(t)} \approx\left|\frac{V_{\mathrm{R}}}{\mathrm{V}_{\mathrm{P}}}\right| \frac{A_{P}(t)}{A_{R, 0} X_{R}(t)}$

Equation 2 Selectivity towards product $\mathrm{P}$ from reactant $\mathrm{R}$.

Few peaks observed on chromatograms were not identified. However, we measure selectivity towards those unidentified molecules (called "unknown GC") by summing their peak areas. In practice, we insure that this proportion is not too high.

We suspect that some heavy molecules cannot be detected by GC-FID for at least two reasons: i) some products cannot be vaporized ii) GC-FID sampling frequency was set to 1 measurement each $45 \mathrm{~min}$, hiding molecules with high retention times. Undetected

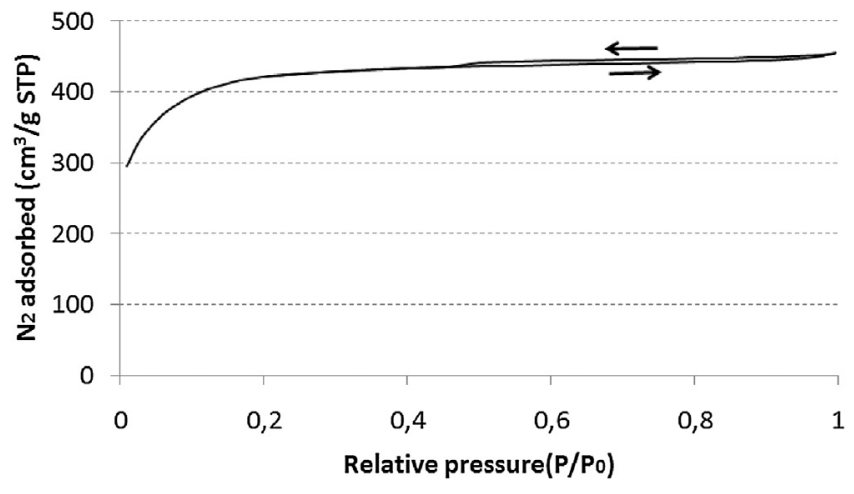

Fig. 2. $\mathrm{N}_{2}$ adsorption/desorption isotherms for Norit RX1.5 EXTRA $\left(C_{\text {norit }}\right)$ raw charcoal containing both micropores and mesopores. Hysteresis phenomenon from 0.5 to 1 attests for the presence of mesopores.

molecule proportions (called "Undetected GC") were calculated by difference.

In addition to online monitoring of the reaction progress, the condensed products were recovered after each test and analyzed off-line by GCxGC-MS to identify potential unknown species. The GC $\times$ GC-MS used was built from an Agilent GC 6890 N coupled with a MS detector (5975B) for identification purpose. The first column is a VF 1701 MS with medium polarity while the second one is a DB1 with low polarity. Separation of the injected products between the two columns is achieved through a cryogenic modulator. A detailed description of this device was previously published by Joffres et al.[53].

\section{Results \& discussion}

\subsection{Catalyst characterization}

Once synthesized, activated charcoal-based catalysts were characterized to determine porous structure parameters, metal oxide amounts, particle sizes as well as initial metal dispersion.

Since mesopores and micropores distribution is expected to significantly affect catalyst performances [32], $\mathrm{N}_{2}$ physisorption (Fig. 2) was performed on the raw activated charcoal (i.e. $C_{\text {norit }}$ ). Hysteresis phenomenon observed for relative pressures in the range $0.5-1$ attest for the presence of mesopores $(2 \mathrm{~nm}<$ pore size $<50 \mathrm{~nm}$ ) in the raw charcoal. The total pore volume is 


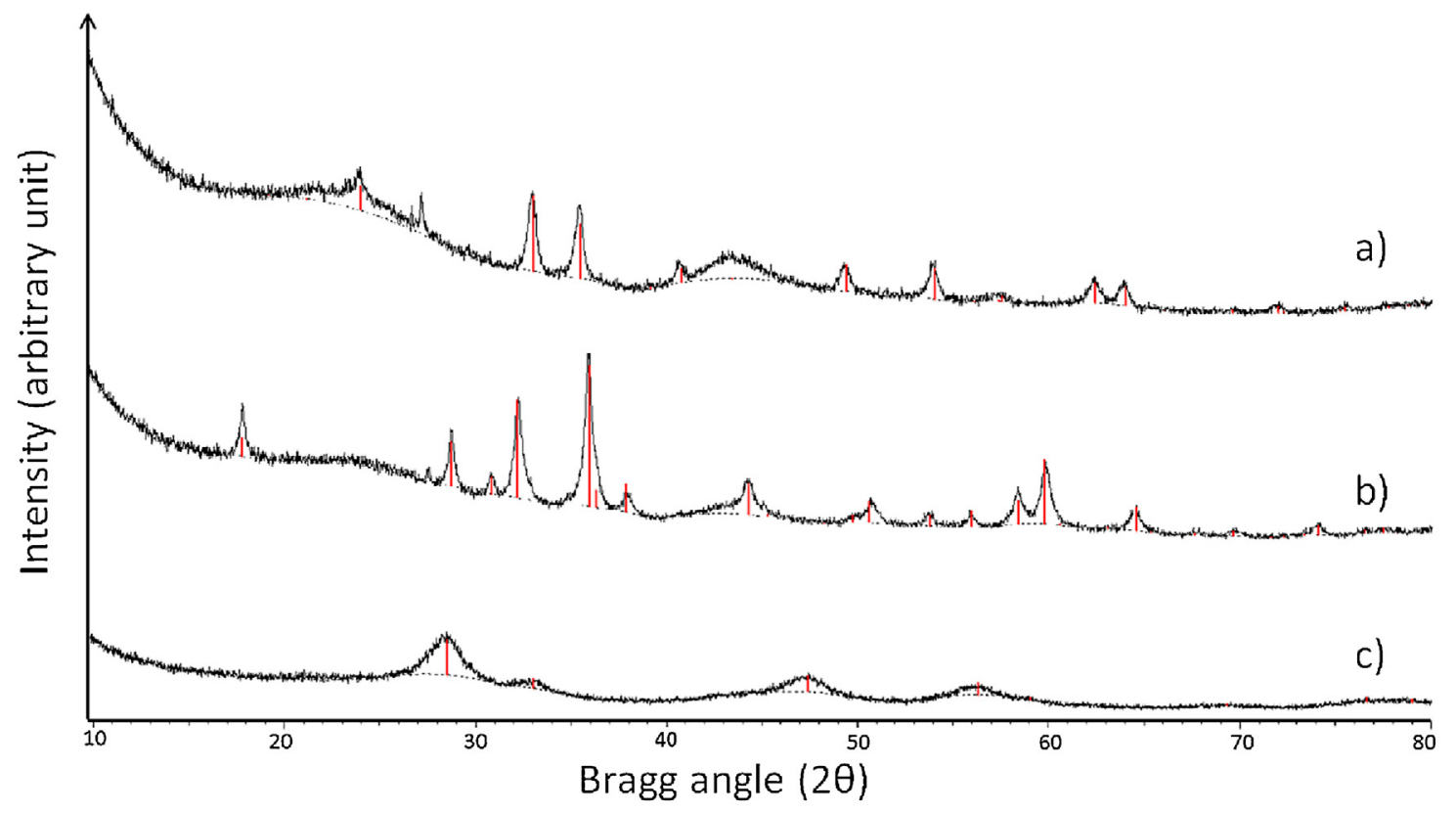

Fig. 3. XRD patterns of the catalysts a) $\mathrm{FeO}_{\mathrm{x}} / \mathrm{C}_{\text {norit }}$, b) $\mathrm{MnO}_{\mathrm{x}} / \mathrm{C}_{\text {norit }}$ and c) $\mathrm{CeO}_{\mathrm{x}} / \mathrm{C}_{\text {norit }}$. Catalytic sites were found to be $\mathrm{Fe}_{2} \mathrm{O}_{3}$ (PDF 04-006-6579), $\mathrm{Mn}_{3} \mathrm{O}_{4}$ ( $\mathrm{PDF}$ 04-007-9641) and $\mathrm{CeO}_{2}$ (PDF 00-043-1002).
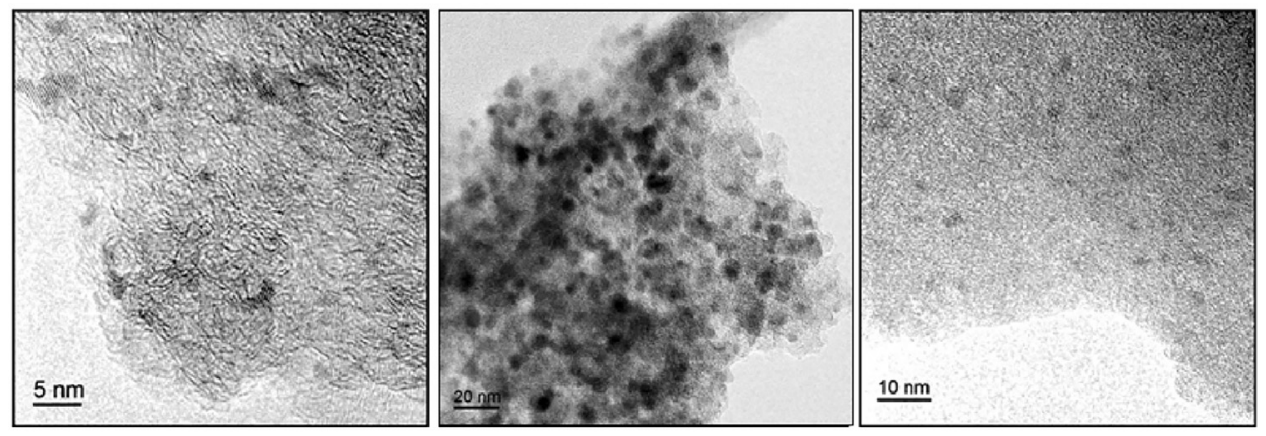

Fig. 4. HRTEM observations of nanoparticles dispersed in activated charcoal-based catalysts. From left to right: $\mathrm{CeO}_{\mathrm{x}} / \mathrm{C}_{\mathrm{norit}}, \mathrm{MnO}_{\mathrm{x}} / \mathrm{C}_{\mathrm{norit}}$ and FeO $\mathrm{x} / \mathrm{C}_{\text {norit. }}$

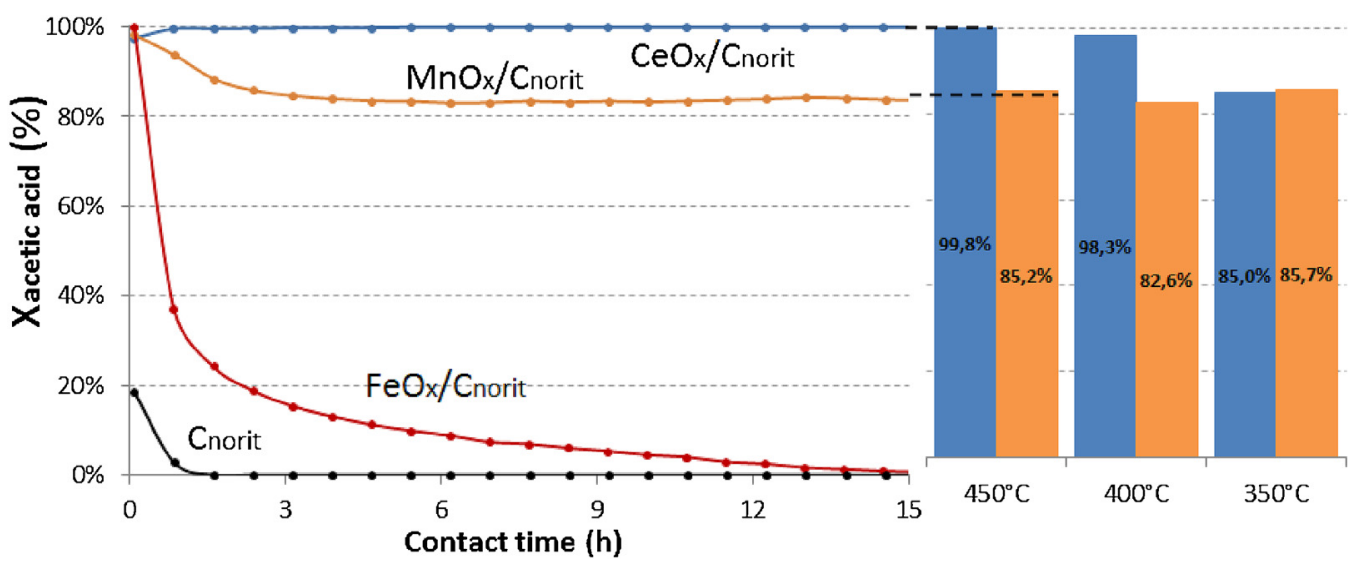

Fig. 5. Left: conversion rates of acetic acid $\left(\mathrm{X}_{\text {aceticacid }}(\mathrm{t})\right)$ measured at $450^{\circ} \mathrm{C}$ over $\mathrm{CeO}_{\mathrm{x}} / \mathrm{C}_{\text {norit }}, \mathrm{MnO}_{\mathrm{x}} / \mathrm{C}_{\text {norit }}, \mathrm{FeO}_{\mathrm{x}} / \mathrm{C}_{\text {norit }}$ and $\mathrm{C}_{\text {norit }}\left(\mathrm{WHSV}=8.1 \mathrm{~h}{ }^{-1}\right)$. Right: mean values of $\mathrm{X}_{\text {aceticacid }}(\mathrm{t})$ at $450^{\circ} \mathrm{C}, 400^{\circ} \mathrm{C}$ and $350^{\circ} \mathrm{C}$ for $\mathrm{CeO}_{\mathrm{x}} / \mathrm{C}_{\text {norit }}$ (blue) and $\mathrm{MnO}_{\mathrm{x}} / \mathrm{C}_{\text {norit }}$ (orange).

$0.71 \mathrm{~cm}^{3} / \mathrm{g}$ and the micropore volume was estimated to reach $0.58 \mathrm{~cm}^{3} / \mathrm{g}$. Thus micropores (pore size $<2 \mathrm{~nm}$ ) represent about $81 \%$ of the internal pore volume of the charcoal.

As shown in Fig. 3, XRD analysis revealed the presence of crystallized nanoparticles which were found to be ceria $\left(\mathrm{CeO}_{2}\right)$, hausmannite $\left(\mathrm{Mn}_{3} \mathrm{O}_{4}\right)$ and hematite $\left(\mathrm{Fe}_{2} \mathrm{O}_{3}\right)$. Mean sizes of crystallites were estimated at $17 \times 17 \times 18 \mathrm{~nm}^{3}$ for hematite, $23 \times 23 \times 18 \mathrm{~nm}^{3}$ for hausmannite and at $3.5 \times 3.5 \times 3.5 \mathrm{~nm}^{3}$ for ceria. 
Dispersion is defined as the ratio of total number of exposed atoms to total number of atoms in the catalyst. Crystallographic models were built using Vesta freeware to determine the initial metal dispersion. Particle shapes of $\mathrm{CeO}_{2}, \mathrm{Fe}_{2} \mathrm{O}_{3}$ and $\mathrm{Mn}_{3} \mathrm{O}_{4}$ were assumed to be respectively cubic, rhombohedral and tetragonal. Based on XRD measurements the number of primitive cells of each nanoparticle was calculated to be $7 \times 7 \times 7$ for ceria, $12 \times 12 \times 13$ for hematite and $40 \times 40 \times 20$ for hausmannite. The number of bulk and surface atoms were determined from these models leading to metal dispersion of $35 \%$ for $\mathrm{Ce}, 5 \%$ for Fe and $3 \%$ for Mn. Very high dispersion of $\mathrm{Ce}$ is consistent with the small size of $\mathrm{CeO}_{2}$ nanoparticles (Fig. 4).

\subsection{Catalytic conversion of acetic acid}

Acetic acid is a major oxygenated compound in bio-oils which also significantly contributes to bio-oil acidity [37]. Acetic acid is a thermally unstable species which can be degraded to form either $\mathrm{CH}_{4}, \mathrm{CO}_{2}, \mathrm{CH}_{2} \mathrm{CO}$ and $\mathrm{H}_{2} \mathrm{O}$ at temperatures above $460^{\circ} \mathrm{C}$ [54,55]. In the presence of catalysts, acetic acid might also condensate to form acetone by ketonic decarboxylation between $300^{\circ} \mathrm{C}$ and $500^{\circ} \mathrm{C}$ (Eq. (3)) $[40,42]$.

$2 \mathrm{CH}_{3} \mathrm{COOH}^{\left[300^{\circ} \mathrm{C}-500^{\circ} \mathrm{C}\right] \text { catalyst }} \mathrm{CH}_{3} \mathrm{COCH}_{3}+\mathrm{CO}_{2}+\mathrm{H}_{2} \mathrm{O}$

Equation 3 Ketonic decarboxylation of acetic acid.

The main goal of this section is to evaluate the activity and the stability of $\mathrm{CeO}_{\mathrm{x}} / \mathrm{C}_{\text {norit }}, \mathrm{FeO}_{\mathrm{x}} / \mathrm{C}_{\text {norit }}$ and $\mathrm{MnO}_{\mathrm{x}} / \mathrm{C}_{\text {norit }}$ to convert acetic acid through ketonic decarboxylation and to inhibit thermal cracking.

Catalytic tests show that, compared to $\mathrm{C}_{\text {norit }}$ support alone, those three metal oxide charcoal based catalysts are suitable to convert acetic acid. The evolution of acetic acid conversion rates during catalytic test runs is presented in Fig. 5. Results demonstrate that the conversion rates obtained with both $\mathrm{CeO}_{\mathrm{x}} / \mathrm{C}_{\text {norit }}$ and $\mathrm{MnO}_{\mathrm{x}} / \mathrm{C}_{\text {norit }}$ catalysts remain very high and stable for $15 \mathrm{~h}$. This result is in good accordance with Glinski et al. who also noticed the great stability of ceria based catalyst $\left(\mathrm{CeO}_{2} / \mathrm{SiO}_{2}\right)$ which converted about $75 \%$ of acetic acid for $15 \mathrm{~h}$ at $350^{\circ} \mathrm{C}$ with a WHSV of $3.1 \mathrm{~h}^{-1}$ [41].

The catalytic activity of $\mathrm{FeO}_{x} / \mathrm{C}_{\text {norit }}$ was expected to be initially high since $\mathrm{Fe}_{2} \mathrm{O}_{3}$ was successfully employed by Kuriacose and Jewur between $330^{\circ} \mathrm{C}$ and $450^{\circ} \mathrm{C}$ at atmospheric pressure in $\mathrm{H}_{2}$ atmosphere [47]. On the other hand, Glinski et al. pointed out that yield of acetone of $52 \%$ could be obtained over $\mathrm{Fe}_{2} \mathrm{O}_{3} / \mathrm{SiO}_{2}$ catalyst at $450{ }^{\circ} \mathrm{C}$ in spite of quick deactivation due to coke deposit [41]. Although we obtained an initial conversion rate close to $100 \%$, we also observed that catalytic activity of $\mathrm{FeO}_{\mathrm{x}} / \mathrm{C}_{\text {norit }}$ quickly decreases until reaching $0 \%$ after $15 \mathrm{~h}$. The quick deactivation of $\mathrm{Fe}_{2} \mathrm{O}_{3}$ is also consistent with Nagashima et al. who show that pure $\mathrm{Fe}_{2} \mathrm{O}_{3}$ has little catalytic activity towards ketonic decarboxylation of propanoic acid into 3-pentanone [56].

The influence of reaction temperature was investigated for both $\mathrm{CeO}_{\mathrm{x}} / \mathrm{C}_{\text {norit }}$ and $\mathrm{MnO}_{\mathrm{x}} / \mathrm{C}_{\text {norit }}$ catalysts. No significant effect of the reaction temperature was observed in the range of $350^{\circ} \mathrm{C}-450^{\circ} \mathrm{C}$ for the Mn-doped catalyst. Concerning $\mathrm{CeO}_{\mathrm{x}} / \mathrm{C}_{\text {norit }}$, the conversion slightly decreased when temperature diminished to reach $98 \%$ at $400{ }^{\circ} \mathrm{C}$ and $85 \%$ at $350^{\circ} \mathrm{C}$.

Although, acetone is the major product, GC-FID online analysis also revealed the presence of methane traces due to thermal cracking of acetic acid [54,55]. However, selectivity towards methane was found to be lower than $2 \%$ for $\mathrm{CeO}_{\mathrm{x}} / \mathrm{C}_{\text {norit }}$ and $\mathrm{MnO}_{\mathrm{x}} / \mathrm{C}_{\text {norit }}$ while it can reach $10 \%$ for $\mathrm{FeO}_{\mathrm{x}} / \mathrm{C}_{\text {norit }}$. Hence, acetone selectivity was close to $98 \%$ when using either $\mathrm{CeO}_{\mathrm{x}} / \mathrm{C}_{\text {norit }}$ or $\mathrm{MnO}_{\mathrm{x}} / \mathrm{C}_{\text {norit }}$ catalysts. This result confirms that thermal decomposition reactions of acetic acid could be neglected and that acetic acid is mainly converted by ketonic decarboxylation. High acetic acid conversion and

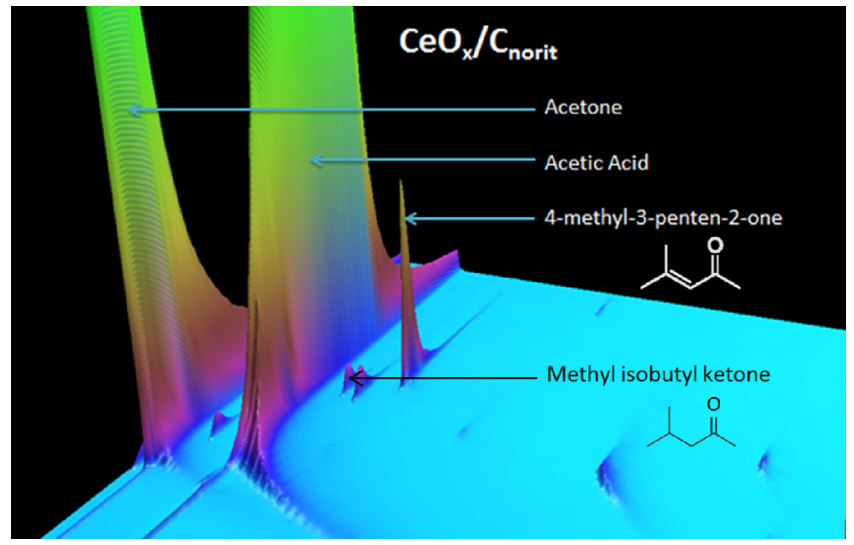

Fig. 6. GCXGC-MS 3D view of the condensates recovered after a catalytic test with $\mathrm{CeO}_{x} / \mathrm{C}_{\text {norit }}$. Note: acetic acid is collected in the condensate pot at the beginning of the test, when the reactor is by-passed.

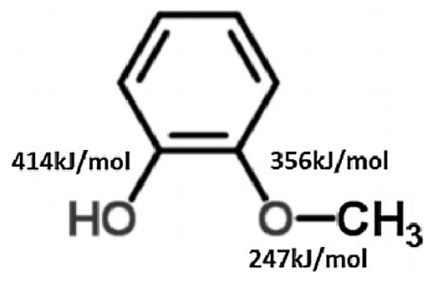

Fig. 7. Oxygen-carbon bond energies in guaiacol [56].

selectivity towards ketonic decarboxylation are in good accordance with the work of Glinski which reported acetone yields above $75 \%$ until $375^{\circ} \mathrm{C}$ using either $\mathrm{CeO}_{2}$ or $\mathrm{MnO}_{2}$ over alumina, silica and titania [41].

At the end of test runs, condensates were also analyzed by GCxGC-MS. Interestingly, for $\mathrm{CeO}_{x} / \mathrm{C}_{\text {norit, }}$, traces of 4-methyl-3penten-2-one and methyl isobutyl ketone were also detected on the chromatogram (Fig. 6). Those molecules, formed by aldol condensation of acetone, reveal that some chain reactions occurred. 4-methyl-3-penten-2-one formation has already been investigated by Crisci et al. [57] Interestingly, it can be noted that those minor products are even more deoxygenated than acetone.

To sum up, activated charcoal catalysts doped with $\mathrm{CeO}_{2}$ and $\mathrm{Mn}_{3} \mathrm{O}_{4}$ were found to efficiently and selectively convert acetic acid through ketonic decarboxylation already at $400^{\circ} \mathrm{C}$. We also demonstrate that those catalysts remain extremely stable for $15 \mathrm{~h}$ whereas iron based catalyst is deactivated.

\subsection{Catalytic conversion of guaiacol}

Usually, guaiacol conversion is studied under hydrogen pressure in hydrodeoxygenation (HDO) operating conditions $\left(350^{\circ} \mathrm{C}\right.$, 50 bar) [58] since this compound is relatively refractory to deoxygenation treatment and needs hydrogen to release water. Due to the methoxy and phenoxy groups and according to bond energies reported in Fig. 7, the two competing reactions which are the most likely to occur with guaiacol are demethylation and demethoxylation, leading to the formation of catechol and phenol respectively [59]. Obviously, high selectivity towards demethoxylation is desirable for deoxygenation purpose. Few studies were undertaken at atmospheric pressure under inert atmosphere and the reactivity here is expected to be low.

The evolution of conversion rates versus time on stream at $400{ }^{\circ} \mathrm{C}$ is presented in Fig. 8. First, we noted that the support alone allowed converting $20 \%$ of guaiacol and the conversion rate is stable for $15 \mathrm{~h}$. For $\mathrm{FeO}_{\mathrm{x}} / \mathrm{C}_{\text {norit }}$ catalyst, the initial conversion 


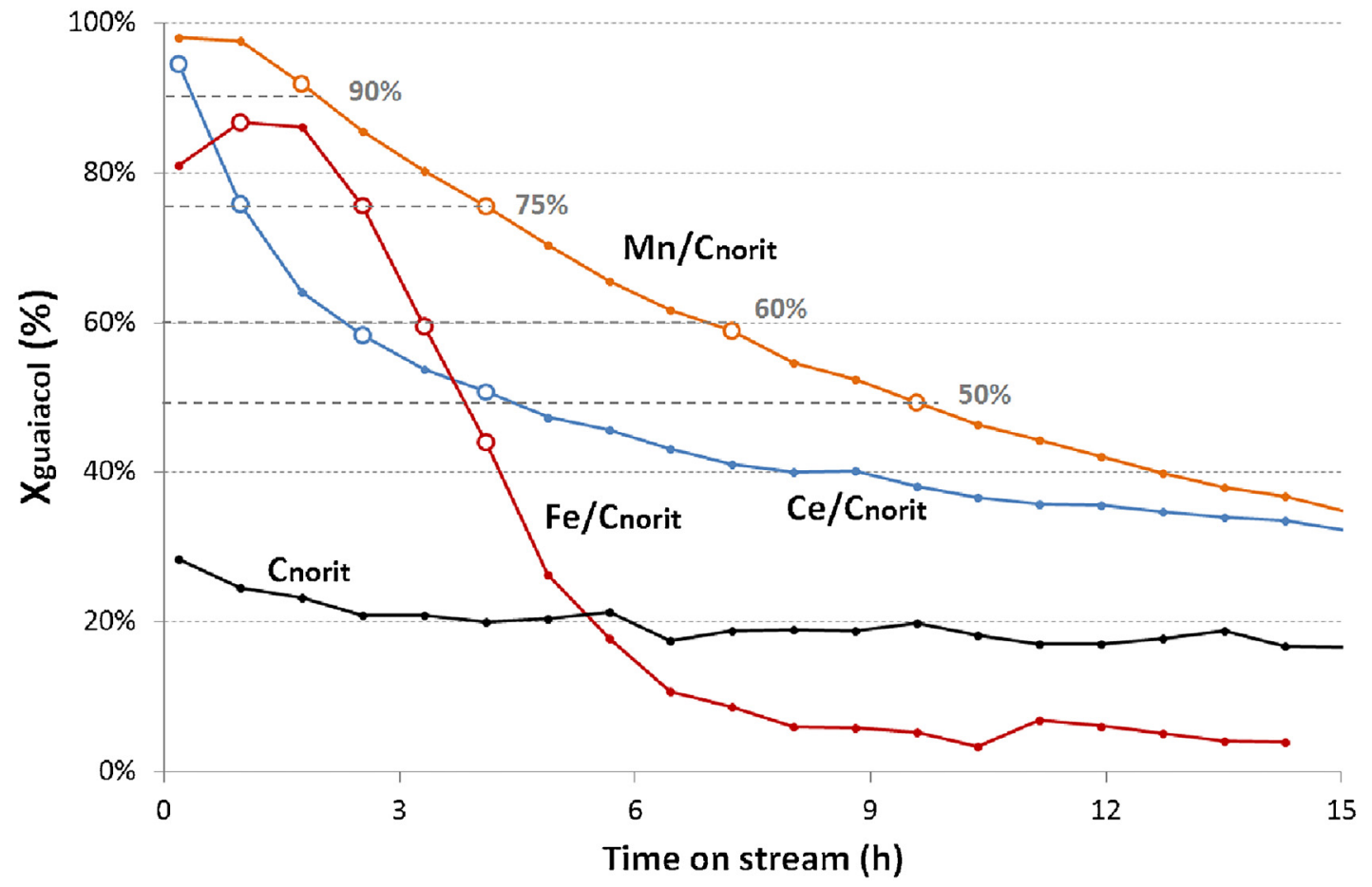

Fig. 8. Evolution of the conversion rates of guaiacol $\left(\mathrm{X}_{\text {guaiacol }}(\mathrm{t})\right)$ at $400^{\circ} \mathrm{C}$ over $\mathrm{CeO}_{\mathrm{x}} / \mathrm{C}_{\text {norit }}, \mathrm{MnO}_{\mathrm{x}} / \mathrm{C}_{\text {norit }}$, FeO $\mathrm{x} / \mathrm{C}_{\text {norit }}$ or $\mathrm{C}_{\text {norit }}$ catalyst $(\mathrm{WHSV}=0.3 \mathrm{~h}-1)$. Circle dots indicate the conversion rates (around 50\%, 60\%, 75\% and 90\%) which were used to measure the selectivities shown in Fig. 9.

rate close to $100 \%$, rapidly decreased until reaching $50 \%$ after $4 \mathrm{~h}$ and $0 \%$ after $15 \mathrm{~h}$. For $\mathrm{CeO}_{\mathrm{x}} / \mathrm{C}_{\text {norit }}$ catalyst, fast deactivation is observed, however, the conversion rate reached a plateau of approximately $35 \%$ after $15 \mathrm{~h}$. An even slower deactivation was observed for $\mathrm{MnO}_{\mathrm{x}} / \mathrm{C}_{\text {norit }}$, as this catalyst still converted more than $50 \%$ of guaiacol after $9 \mathrm{~h}$ at $400^{\circ} \mathrm{C}$. However after $15 \mathrm{~h}$, the catalysts $\mathrm{CeO}_{\mathrm{x}} / \mathrm{C}_{\text {norit }}$ and $\mathrm{MnO}_{\mathrm{x}} / \mathrm{C}_{\text {norit }}$ reached the same conversion rate. Hence, $\mathrm{MnO}_{\mathrm{x}} / \mathrm{C}_{\text {norit }}$ was slightly more active than $\mathrm{CeO}_{\mathrm{x}} / \mathrm{C}_{\text {norit }}$ at $400{ }^{\circ} \mathrm{C}$. We note that the conversion rate of guaiacol with $\mathrm{FeO}_{\mathrm{x}} / \mathrm{C}_{\text {norit }}$ is lower than the conversion rate obtained with the support after $5 \mathrm{~h}$. This can be due to quick pore blocking of $\mathrm{FeO}_{\mathrm{x}} / \mathrm{C}_{\text {norit }}$ which inhibits activity of carbon.

In Fig. 9, the selectivities measured for each catalyst at conversion rates close to $90 \%, 75 \%, 60 \%$ and $50 \%$ are reported. As expected, catechol and phenol were the main reaction products among species detected by GC-FID. More specifically, the selectivity towards phenol decreased and catechol formation increased while the conversion rates decreased. Ic ( $\mathrm{C}(\mathrm{sp} 3)$-OMe) cleavage is more likely to occur for a more active catalyst, leading to phenol formation. While catalyst deactivates, the probability of aryl-ether bond splitting decreases. Since methyl-ether ( $\mathrm{C}(\mathrm{sp} 3)-\mathrm{OAr})$ binding energy is lower than those of aryl-ether and hydroxy bonds, catechol selectivity rises as catalyst activity declines. It is thus difficult to compare the three catalysts as the deactivation rate is different.

$\mathrm{FeO}_{\mathrm{x}} / \mathrm{C}_{\text {norit }}$ was the most selective catalyst towards phenol formation and at high conversion rate, before deactivation, traces of benzene were initially detected, revealing a possible cleavage of both methoxy and hydroxy groups with this catalyst. Whereas, $\mathrm{MnO}_{\mathrm{x}} / \mathrm{C}_{\text {norit }}$ - which was the most active catalyst - favored catechol formation even at high conversion rate before any deactivation.

Minor reaction products, such as methanol, cresol, dimethylphenols and trimethylphenols were also detected. Methanol is formed by demethoxylation of guaiacol, i.e. by $\mathrm{C}_{(\mathrm{sp2})^{-}}$ OMe bond cleavage at the same time as phenol direct formation.
Methylated derivatives were formed by methylation of phenol aromatic rings, on more acidic catalytic sites [60].

For $\mathrm{C}_{\text {norit }}$ support alone, the conversion rate reached $20 \%$ and remained stable for $15 \mathrm{~h}$. Selectivities towards catechol, cresol, methanol and phenol were respectively $69 \%, 11 \%, 7 \%$ and $4 \%$ (not shown on Fig. 9). It indicates that the carbonaceous support is not inert during guaiacol conversion rate and possesses few acidic catalytic sites for demethylation and methylation steps. Thus, when the supported metal oxide catalysts deactivate their catalytic activity shifts towards the support catalytic activity.

Summing all the selectivities, one can observed that $17 \%$ to $54 \%$ of the products were not detected by GC-FID. Those species probably correspond to high molar weight molecules which cannot be vaporized in GC or have high retention times. Coke is certainly a part of undetected molecules. However, as our catalysts were prepared on carbon support, coke content cannot be evaluated by CHONS analysis as usual. To complete online GC-FID measurements, the condensates recovered after each experiment were analyzed by GCxGC-MS (Fig. 10). Interestingly, a large variety of dimers was identified in the condensate obtained with $\mathrm{FeO}_{\mathrm{x}} / \mathrm{C}_{\text {norit }}$ catalyst and to a lesser extent with $\mathrm{CeO}_{\mathrm{x}} / \mathrm{C}_{\text {norit }}$ (Fig. 11). This result attests that polymerization reactions occur during the conversion. According to us, the presence of those dimers tends to prove that polymerized products may condensate over catalytic sites leading to coke formation [31].

Under high pressure of hydrogen, radical species were probably formed but rapidly react with hydrogen radical species and dimerization or condensation reactions were not observed. However, in our operating conditions, under inert atmosphere and at high temperatures, the radical species formation was favored and radical coupling occurred to lead dimers and possibly oligomers.

Although this assumption has to be confirmed, it suggests that quick deactivation of $\mathrm{FeO}_{\mathrm{x}} / \mathrm{C}_{\text {norit }}$ catalyst - and to a lesser extent $\mathrm{CeO}_{\mathrm{x}} / \mathrm{C}_{\text {norit }}$ - occurs by either coke deposition on catalytic sites or pore blocking. Furthermore, the tendency to $\mathrm{FeO}_{\mathrm{x}} / \mathrm{C}_{\text {norit }}$ to enhance polymerized product - which probably cause pore blocking - may 


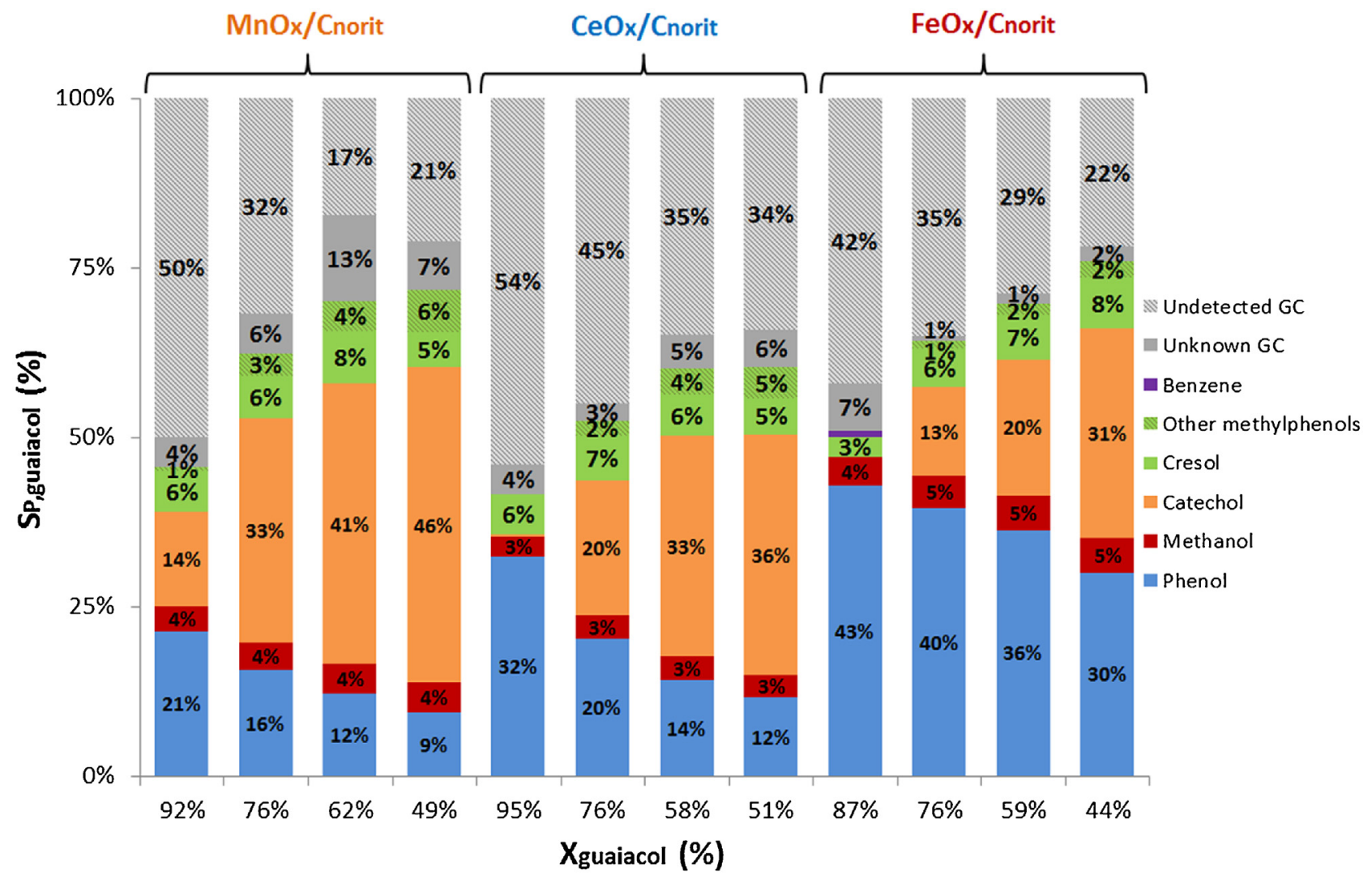

Fig. 9. Evolution of selectivities $\left(\mathrm{S}_{\mathrm{P} \text {,guaiacol }}\right)$ as a function of guaiacol conversion rate $\left(\mathrm{X}_{\text {guaiacol }}\right)$ at $400{ }^{\circ} \mathrm{C}$ for $\mathrm{CeO}_{\mathrm{x}} / \mathrm{C}_{\mathrm{norit}}, \mathrm{MnO}_{\mathrm{x}} / \mathrm{C}_{\mathrm{norit}}$ and FeO $\mathrm{x} / \mathrm{C}_{\mathrm{norit}} \mathrm{Catalysts}$ "Other methylphenols" is a generic term for dimethylphenols and trimethylphenols. "Unknown GC" integrates all peaks which were not identified on chromatograms from GC-FID. Undetected species proportions ("Undetected GC") were calculated by difference, they mainly correspond to heavy species which cannot be vaporized and thus detected by GC. Note: since we assess constant response factors, methanol selectivity is slightly overestimated compared to aromatic products - benzene, methylphenols, catechol, phenol - which have a close carbon atom number.

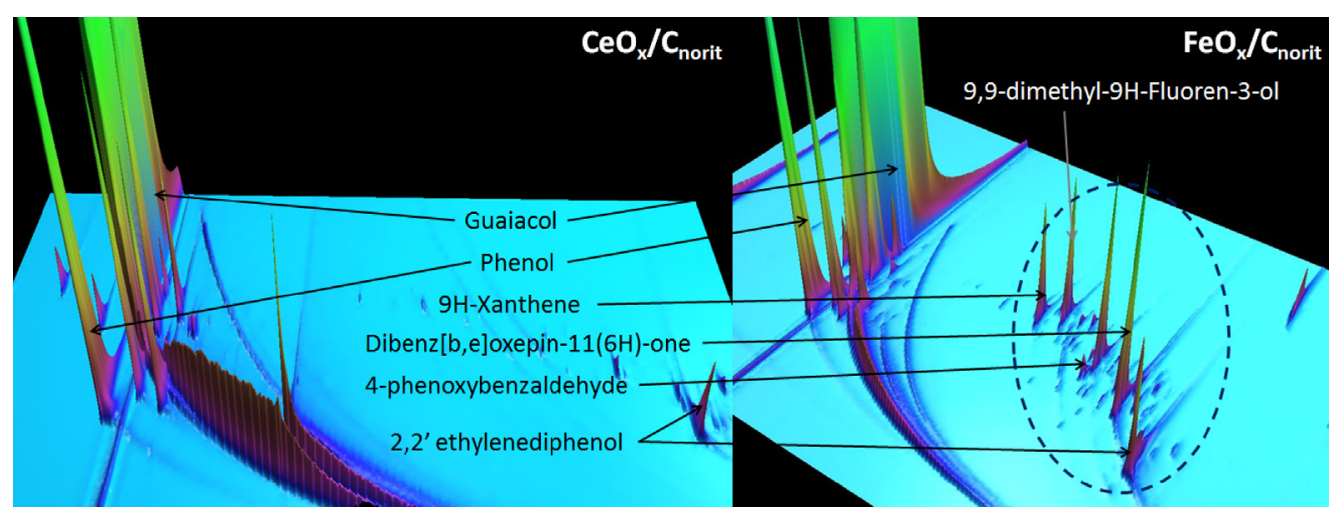

Fig. 10. 3D chromatograms of liquid condensates recovered after test runs. More dimers were detected in the condensate for FeO $\mathrm{O}_{\mathrm{x}} / \mathrm{C}_{\mathrm{norit}}$.

explain why conversion rate in the presence of those catalyst was lower than with the support alone after $5 \mathrm{~h}$ of conversion.

\section{Conclusion}

The objective of this study was to investigate the performances of activated charcoal-based catalysts to deoxygenate two biomass pyrolytic vapor model compounds: acetic acid and guaiacol. Experiments were performed using Norit RX1.5 EXTRA, a weakly acidic and relatively cheap microporous support, which is partially mesoporous. Catalyst preparation - by impregnation followed by vacuum solvent removal - has been found relevant to obtain a good distribution of nanosized catalytic particles.
Among the tested catalysts, $\mathrm{CeO}_{\mathrm{x}} / \mathrm{C}_{\text {norit }}$ allowed full acetic acid conversion by ketonic decarboxylation already at $400^{\circ} \mathrm{C}$. High conversion rate of acetic acid was also obtained with $\mathrm{MnO}_{\mathrm{x}} / \mathrm{C}_{\text {norit }}$ catalyst in the range $350^{\circ} \mathrm{C}-450^{\circ} \mathrm{C}$. Besides their high activity and selectivity towards ketonic decarboxylation, those catalysts were also very stable over time. On the other hand, Fe-based catalyst was not appropriate to convert acetic acid as it deactivated quickly.

For guaiacol conversion, deoxygenation could be achieved by cleavage of aryl-ether, methyl-ether or hydroxy bonds. However, we found that hydroxy bond is hardly cleaved with the tested catalysts at $400^{\circ} \mathrm{C}$. Hence, only partial deoxygenation could be achieved by methoxy group cleavage, leading mainly to phenol formation. $\mathrm{FeO}_{\mathrm{x}} / \mathrm{C}_{\text {norit }}$ catalyst was found to be more selective than $\mathrm{MnO}_{\mathrm{x}} / \mathrm{C}_{\text {norit }}$ 


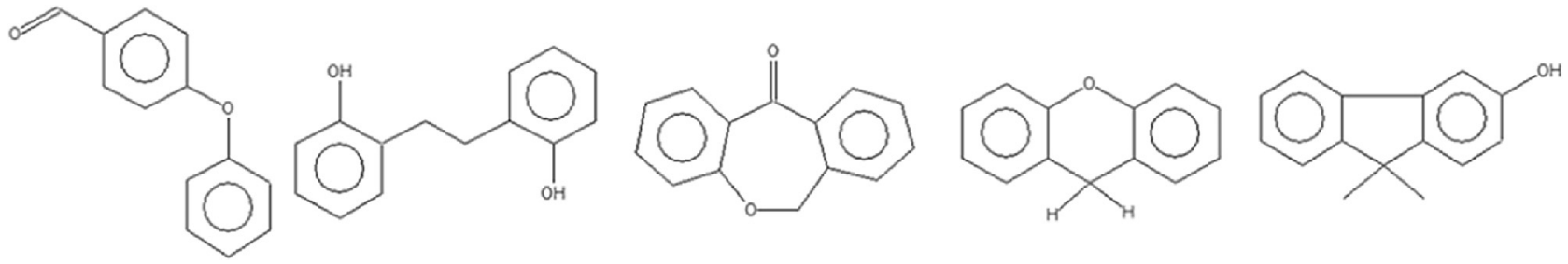

Fig. 11. Dimers detected in condensates. From left to right: 4-phenoxybenzaldehyde (CAS: 67-36-7), 2,2'ethylenediphenol (CAS: 29338-20-3), dibenz[b,e]oxepin-11(6H)-one (CAS: 4504-87-4), 9H-xanthene (CAS: 92-83-1) and 9,9dimethyl-9H-fluoren-3-ol.

towards phenol formation, but it also deactivated more quickly. $\mathrm{CeO}_{\mathrm{x}} / \mathrm{C}_{\text {norit }}$ catalyst yielded intermediate performance. Catalytic performance of tested catalysts was at least divided by a factor of two after $9 \mathrm{~h}$ on stream. Traces of dimeric compounds attest for the occurrence of polymerization reactions during the conversion. Since polymerized products tend to form coke, we suggest that catalyst deactivation mainly occurs by either pore blocking or carbon deposition on the catalytic sites.

This study demonstrates the great potential of activated charcoal-based catalysts to convert model compounds derived from biomass pyrolysis. Further investigation is now required directly with pyrolytic vapors to evaluate the catalyst performance in real conditions. Last but not least, a comparison with zeolites or mesoporous catalysts will give fruitful results to achieve a better deoxygenation of bio-oils.

\section{Acknowledgments}

This work was co-funded by CIRAD and ADEME, and received financial support from Agence Nationale de la Recherche. The authors sincerely acknowledge Claude Mirodatos (CNRSIRCELyon), Martin Drobek (CNRS-IEM-Montpellier) and Bruno Gagnepain (ADEME) for their scientific advices as well as Emmanuel Leclerc, Chantal Lorentz, Yoann Aizac and Nathalie Troalen for technical and administrative support. The authors are grateful to Cabot Corporation for providing us activated charcoal samples.

\section{References}

[1] D. Mohan, C.U. Pittman, P.H. Steele, Pyrolysis of wood/biomass for bio-oil: a critical review, Energy Fuels 20 (2006) 848-889, http://dx.doi.org/10.1021/ ef0502397.

[2] P.M. Mortensen, J.D. Grunwaldt, P.A. Jensen, K.G. Knudsen, A.D. Jensen, A review of catalytic upgrading of bio-oil to engine fuels, Appl. Catal. A 407 (2011) 1-19.

[3] J.P. Diebold, A Review of the Chemicals and Physical Mechanisms of the Storage Stability of Fast Pyrolysis Bio-oils, National Renewable Energy Laboratory, Golden, CO, 2000 .

[4] A.V. Bridgwater, Upgrading biomass fast pyrolysis liquids, Environ. Prog. Sustain. Energy 31 (2012) 261-268.

[5] M.S. Abu Bakar, J.O. Titiloye, Catalytic pyrolysis of rice husk for bio-oil production, J. Anal. Appl. Pyrolysis 103 (2013) 362-368, http://dx.doi.org/10. 1016/j.jaap.2012.09.005.

[6] A. Aho, N. Kumar, K. Eränen, T. Salmi, M. Hupa, D.Y. Murzin, Catalytic pyrolysis of woody biomass in a fluidized bed reactor: influence of the zeolite structure. Fuel 87 (2008) 2493-2501, http://dx.doi.org/10.1016/j.fuel.2008.02.015.

[7] M. Olazar, R. Aguado, J. Bilbao, A. Barona, Pyrolysis of sawdust in a conical spouted-bed reactor with a HZSM-5 catalyst, AIChE J. 46 (2000) 1025-1033.

[8] H.S. Choi, D. Meier, Fast pyrolysis of Kraft lignin-vapor cracking over various fixed-bed catalysts, J. Anal. Appl. Pyrolysis 100 (2013) 207-212, http://dx.doi. org/10.1016/j.jaap.2012.12.025.

[9] R. French, S. Czernik, Catalytic pyrolysis of biomass for biofuels production, Fuel Process. Technol. 91 (2010) 25-32, http://dx.doi.org/10.1016/j.fuproc. 2009.08.011.

[10] T.R. Carlson, J. Jae, Y.-C. Lin, G.A. Tompsett, G.W. Huber, Catalytic fast pyrolysis of glucose with HZSM-5: The combined homogeneous and heterogeneous reactions, J. Catal. 270 (2010) 110-124, http://dx.doi.org/10.1016/j.jcat.2009. 12.013.

[11] A.J. Foster, J. Jae, Y.-T. Cheng, G.W. Huber, R.F. Lobo, Optimizing the aromatic yield and distribution from catalytic fast pyrolysis of biomass over ZSM-5, Appl. Catal. Gen. 423-424 (2012) 154-161, http://dx.doi.org/10.1016/j.apcata. 2012.02.030.
[12] A.G. Gayubo, A.T. Aguayo, A. Atutxa, R. Aguado, J. Bilbao, Transformation of oxygenate components of biomass pyrolysis oil on a HZSM-5 zeolite. I. Alcohols and phenols, Ind. Eng. Chem. Res. 43 (2004) 2610-2618.

[13] P.A. Horne, P.T. Williams, Reaction of oxygenated biomass pyrolysis model compounds over a ZSM-5 catalyst, Renew. Energy 7 (1996) 131-144.

[14] E.F. Iliopoulou, S.D. Stefanidis, K.G. Kalogiannis, A. Delimitis, A.A. Lappas, K.S. Triantafyllidis, Catalytic upgrading of biomass pyrolysis vapors using transition metal-modified ZSM-5 zeolite, Appl. Catal. B Environ. 127 (2012) 281-290, http://dx.doi.org/10.1016/j.apcatb.2012.08.030.

[15] P.A. Horne, P.T. Williams, Upgrading of biomass-derived pyrolytic vapours over zeolite ZSM-5 catalyst, Fuel 75 (1996) 1043-1050.

[16] Z. Ma, E. Troussard, J.A. van Bokhoven, Controlling the selectivity to chemicals from lignin via catalytic fast pyrolysis, Appl. Catal. Gen. 423-424 (2012) 130-136, http://dx.doi.org/10.1016/j.apcata.2012.02.027.

[17] A. Aho, T. Salmi, D.Y. Murzin, Catalytic pyrolysis of lignocellulosic biomass, in: Elsevier (Ed.), Role Catal. Sustain. Prod. Bio-Fuels Bio-Chem., Amsterdam, 2012, pp. 137-159.

[18] Y.T. Cheng, J. Jae, J. Shi, W. Fan, G.W. Huber, Production of renewable aromatic compounds by catalytic fast pyrolysis of lignocellulosic biomass with bifunctional Ga/ZSM-5 catalysts, Angew. Chem. Int. Ed. Engl. 51 (2012) 1416-1419, http://dx.doi.org/10.1002/anie.201107390.

[19] D.J. Mihalcik, C.A. Mullen, A.A. Boateng, Screening acidic zeolites for catalytic fast pyrolysis of biomass and its components, J. Anal. Appl. Pyrolysis 92 (2011) 224-232, http://dx.doi.org/10.1016/j.jaap.2011.06.001.

[20] C.A. Mullen, A.A. Boateng, D.J. Mihalcik, N.M. Goldberg, Catalytic fast pyrolysis of white oak wood in a bubbling fluidized bed, Energy Fuels 25 (2011) 5444-5451, http://dx.doi.org/10.1021/ef201286z.

[21] T.S. Nguyen, M. Zabeti, L. Lefferts, G. Brem, K. Seshan, Catalytic upgrading of biomass pyrolysis vapours using faujasite zeolite catalysts, Biomass Bioenergy 48 (2013) 100-110, http://dx.doi.org/10.1016/j.biombioe.2012.10.024.

[22] A. Aho, N. Kumar, A.V. Lashkul, K. Eränen, M. Ziolek, P. Decyk, T. Salmi, B. Holmbom, M. Hupa, D.Y. Murzin, Catalytic upgrading of woody biomass derived pyrolysis vapours over iron modified zeolites in a dual-fluidized bed reactor, Fuel 89 (2010) 1992-2000, http://dx.doi.org/10.1016/j.fuel.2010.02. 009.

[23] E. Antonakou, A. Lappas, M.H. Nilsen, A. Bouzga, M. Stöcker, Evaluation of various types of Al-MCM-41 materials as catalysts in biomass pyrolysis for the production of bio-fuels and chemicals, Fuel 85 (2006) 2202-2212, http:// dx.doi.org/10.1016/j.fuel.2006.03.021.

[24] M.H. Nilsen, E. Antonakou, A. Bouzga, A. Lappas, K. Mathisen, M. Stöcker, Investigation of the effect of metal sites in Me-Al-MCM-41 ( $\mathrm{Me}=\mathrm{Fe}, \mathrm{Cu}$ or $\mathrm{Zn})$ on the catalytic behavior during the pyrolysis of wooden based biomass, Microporous Mesoporous Mat. 105 (2007) 189-203, http://dx.doi.org/10. 1016/j.micromeso.2007.05.059.

[25] M.C. Samolada, A. Papafotica, I.A. Vasalos, Catalyst evaluation for catalytic biomass pyrolysis, Energy Fuels 14 (2000) 1161-1167, http://dx.doi.org/10. 1021/Ef000026b.

[26] O.D. Mante, J.A. Rodriguez, S.D. Senanayake, S.P. Babu, Catalytic conversion of biomass pyrolysis vapors into hydrocarbon fuel precursors, Greem Chem. 17 (2015) 2362-2368, http://dx.doi.org/10.1039/c4gc02238f.

[27] S. Wan, T. Pham, S. Zhang, L. Lobban, D. Resasco, R. Mallinson, Direct catalytic upgrading of biomass pyrolysis vapors by a dual function $\mathrm{Ru} / \mathrm{TiO}$ catalyst, AIChE J. 59 (2013) 2275-2285, http://dx.doi.org/10.1002/aic.14038.

[28] S.D. Stefanidis, K.G. Kalogiannis, E.F. Iliopoulou, A.A. Lappas, P.A. Pilavachi, In-situ upgrading of biomass pyrolysis vapors: catalyst screening on a fixed bed reactor, Bioresour. Technol. 102 (2011) 8261-8267, http://dx.doi.org/10. 1016/j.biortech.2011.06.032.

[29] M.A. Patel, M.A.S. Baldanza, V. Teixeira da Silva, A.V. Bridgwater, In situ catalytic upgrading of bio-oil using supported molybdenum carbide, Appl. Catal. Gen. 458 (2013) 48-54, http://dx.doi.org/10.1016/j.apcata.2013.03.029.

[30] A. Imran, E.A. Bramer, K. Seshan, G. Brem, High quality bio-oil from catalytic flash pyrolysis of lignocellulosic biomass over alumina-supported sodium carbonate, Fuel Process. Technol. 127 (2014) 72-79, http://dx.doi.org/10. 1016/j.fuproc.2014.06.011.

[31] C.H. Bartholomew, Mechanisms of catalyst deactivation, Appl. Catal. Gen. 212 (2001) 17-60.

[32] G.T. Neumann, J.C. Hicks, Novel hierarchical cerium-incorporated MFI zeolite catalysts for the catalytic fast pyrolysis of lignocellulosic biomass, ACS Catal. 2 (2012) 642-646, http://dx.doi.org/10.1021/cs200648q.

[33] A. Goncalves, J. Silvestre-Albero, E.V. Ramos-Fernández, J.C. Serrano-Ruiz J.J.M. Órfão, A. Sepúlveda-Escribano, M.F.R. Pereira, Highly dispersed ceria on 
activated carbon for the catalyzed ozonation of organic pollutants, Appl. Catal. B Environ. 113-114 (2012) 308-317, http://dx.doi.org/10.1016/j.apcatb.2011. 11.052

[34] P. Serp, J.L. Figueiredo, Carbon Materials for Catalysis, John Wiley \& Sons, 2009.

[35] M. Ishikawa, M. Tamura, Y. Nakagawa, K. Tomishige, Demethoxylation of guaiacol and methoxybenzenes over carbon-supported Ru-Mn catalyst, Appl. Catal. B Environ. 182 (2016) 193-203, http://dx.doi.org/10.1016/j.apcatb. 2015.09.021.

[36] A.M. Azeez, D. Meier, J. Odermatt, T. Willner, Fast pyrolysis of african and european lignocellulosic biomasses using py-GC/MS and fluidized bed reactor, Energy Fuels 24 (2010) 2078-2085, http://dx.doi.org/10.1021/ef9012856.

[37] A. Oasmaa, D.C. Elliott, J. Korhonen, Acidity of biomass fast pyrolysis bio-oils, Energy Fuels 24 (2010) 6548-6554, http://dx.doi.org/10.1021/ef100935r.

[38] C.A. Gaertner, J.C. Serrano-Ruiz, D.J. Braden, J.A. Dumesic, Ketonization reactions of carboxylic acids and esters over ceria-zirconia as biomass-upgrading processes, Ind. Eng. Chem. Res. 49 (2010) 6027-6033, http://dx.doi.org/10.1021/ie1004338.

[39] E.F. Iliopoulou, Review of C-C coupling reactions in biomass exploitation processes, Curr. Org. Synth. 7 (2010) 587-598, http://dx.doi.org/10.2174/ 157017910794328592.

[40] M. Renz, Ketonization of carboxylic acids by decarboxylation: mechanism and scope, Eur. J. Org. Chem. 2005 (2005) 979-988, http://dx.doi.org/10.1002/ejoc. 200400546.

[41] M. Glinski, J. Kijenski, A. Jakubowski, Ketones from monocarboxylic acids: catalytic ketonization over oxide systems, Appl. Catal. Gen. 128 (1995) 209-217.

[42] L. Vivier, D. Duprez, Ceria-based solid catalysts for organic chemistry, ChemSusChem 3 (2010) 654-778, http://dx.doi.org/10.1002/cssc.201000054.

[43] K.M. Dooley, A.K. Bhat, C.P. Plaisance, A.D. Roy, Ketones from acid condensation using supported $\mathrm{CeO} 2$ catalysts: effect of additives, Appl. Catal. Gen. 320 (2007) 122-133, http://dx.doi.org/10.1016/j.apcata.2007.01.021.

[44] R.W. Snell, B.H. Shanks, Ceria calcination temperature influence on acetic acid ketonization: mechanistic insights, Appl. Catal. Gen. 451 (2013) 86-93, http:// dx.doi.org/10.1016/j.apcata.2012.08.043.

[45] R.W. Snell, S.H. Hakim, J.A. Dumesic, B.H. Shanks, Catalysis with ceria nanocrystals: bio-oil model compound ketonization, Appl. Catal. Gen. 464-465 (2013) 288-295, http://dx.doi.org/10.1016/j.apcata.2013.06.003.

[46] T.N. Pham, T. Sooknoi, S.P. Crossley, D.E. Resasco, Ketonization of carboxylic acids: mechanisms, catalysts, and implications for biomass conversion, ACS Catal. 3 (2013) 2456-2473, http://dx.doi.org/10.1021/cs400501h.

[47] J.C. Kuriacose, S.S. Jewur, Studies on the surface interaction of acetic acid on iron oxide, J. Catal. 50 (1977) 330-341, http://dx.doi.org/10.1016/00219517(77)90042-2.
[48] F.C. Calaza, T.-L. Chen, D.R. Mullins, Y. Xu, S.H. Overbury, Reactivity and reaction intermediates for acetic acid adsorbed on CeO2(1 11 ), Catal. Ceria 253 (2015) 65-76, http://dx.doi.org/10.1016/j.cattod.2015.03.033.

[49] C. Amen-Chen, H. Pakdel, C. Roy, Production of monomeric phenols by thermochemical conversion of biomass: a review, Bioresour. Technol. 79 (2001) 277-299, http://dx.doi.org/10.1016/S0960-8524(00)00180-2.

[50] K. Bourikas, C. Kordulis, A. Lycourghiotis, The role of the liquid-solid interface in the preparation of supported catalysts, Catal. Rev. 48 (2006) 363-444, http://dx.doi.org/10.1080/01614940600962321.

[51] M.M. Dubinin, E.D. Zaverina, L.V. Radushkevich, Sorption and structure of active carbons. I. Adsorption of organic vapors, Zhurnal Fiz. Khimii. 21 (1947) $151-162$.

[52] W.A. Dietz, Response factors for gas chromatographic analyses, J. Chromatogr. Sci. 5 (1967) 68-71, http://dx.doi.org/10.1093/chromsci/5.2.68.

[53] B. Joffres, C. Lorentz, M. Vidalie, D. Laurenti, A.A. Quoineaud, N. Charon, A. Daudin, A. Quignard, C. Geantet, Catalytic hydroconversion of a wheat straw soda lignin: characterization of the products and the lignin residue, Appl. Catal. B Environ. 145 (2014) 167-176, http://dx.doi.org/10.1016/j.apcatb. 2013.01039.

[54] P.G. Blake, G.E. Jackson, The thermal decomposition of acetic acid, J. Chem. Soc. B Phys. Org. (1968) 1153-1155, http://dx.doi.org/10.1039/j29680001153.

[55] P.G. Blake, G.E. Jackson, High-and low-temperature mechanisms in the thermal decomposition of acetic acid, J. Chem. Soc. B Phys. Org. (1969) 94-96, http://dx.doi.org/10.1039/J29690000094.

[56] O. Nagashima, S. Sato, R. Takahashi, T. Sodesawa, Ketonization of carboxylic acids over CeO2-based composite oxides, J. Mol. Catal. Chem. 227 (2005) 231-239, http://dx.doi.org/10.1016/j.molcata.2004.10.042.

[57] A.J. Crisci, H. Dou, T. Prasomsri, Y. Román-Leshkov, Cascade reactions for the continuous and selective production of isobutene from bioderived acetic acid over zinc-Zirconia catalysts, ACS Catal. 4 (2014) 4196-4200, http://dx.doi.org/ 10.1021/cs501018k

[58] V.N. Bui, D. Laurenti, P. Afanasiev, C. Geantet, Hydrodeoxygenation of guaiacol with CoMo catalysts. Part I: Promoting effect of cobalt on HDO selectivity and activity, Appl. Catal. B Environ. 101 (2011) 239-245, http://dx.doi.org/10. 1016/j.apcatb.2010.10.025.

[59] M.T. Klein, Lignin Thermolysis Pathways, Massachussetts Institute of Technology, 1981

[60] V.N. Bui, D. Laurenti, P. Delichère, C. Geantet, Hydrodeoxygenation of guaiacol Part II: Support effect for CoMoS catalysts on HDO activity and selectivity, Appl. Catal. B Environ. 101 (2011) 246-255, http://dx.doi.org/10.1016/j. apcatb.2010.10.031. 